\title{
Novel Bioplastic from Single Cell Protein as a Potential Packaging Material
}

\author{
Shuvra Singha,* Muhamed Mahmutovic, Carlos Zamalloa, Lutgart Stragier, Willy Verstraete, \\ Anna J. Svagan, Oisik Das, and Mikael S. Hedenquist*
}

Cite This: ACS Sustainable Chem. Eng. 2021, 9, 6337-6346

Read Online

\section{ACCESS | Lill Metrics \& More | 回 Article Recommendations ｜（） Supporting Information}

ABSTRACT: Microbial treatment of biodegradable wastes not only ensures neutralization of harmful substances such as volatile organic compounds but also enables valorization and biocircularity within the society. Single cell protein (SCP) is a value-added product that can be obtained from biodegradable waste materials such as food waste via microbial fermentation. In this article, SCP derived from potato starch waste was demonstrated as a viable alternative to existing plant/animal proteins used in the production of films, for example, packaging applications. Flexible glycerol-plasticized SCP films were prepared through compression molding, and tensile tests revealed strength and stiffness similar to other plasticized protein films. The oxygen barrier properties were significantly better compared to the common polyethylene packaging material, but as with other highly polar materials, the SCP material must be shielded from moisture if used in, for example, food packaging. The biodegradation test revealed a similar degradation pattern as observed for a household compostable bag. The results showed that SCP-based bioplastic films can be considered as potential alternative to the existing plant/animal protein films and certain synthetic polymers. An important advantage with these protein materials is that they do not cause problems similar to microplastics.

KEYWORDS: single cell protein, protein, bioplastic, biopolymer, films

\section{INTRODUCTION}

Proteins from plant/animal products have been in focus as renewable raw materials for nonfood applications, particularly for food packaging, owing to their facile film-forming ability and biodegradability. ${ }^{1,2}$ Unlike other bio-sourced homopolymeric polymers (e.g., polysaccharides such as cellulose), proteins are heteropolymeric chains containing different amino acids. This confers a rich variety of chemical functionalities for interactions that are responsible for the formation of $\alpha$-helices, $\beta$-sheet, and $\beta$-turn conformations in proteins. ${ }^{3,4}$ It is these interactions that give rise to the filmforming property of proteins and hence have been used to produce bioplastic films and coatings. ${ }^{5}$ Today's protein-based bioplastics are produced from plant [wheat gluten (WG), soy, pea, corn zein, cottonseed protein, and so forth] and animal (whey, casein, collagen, gelatin, keratin, fish myofibrillar protein, and so forth) sources. ${ }^{6-8}$ However, some of these do not completely comply with the UN's sustainable development goals, as they compete with arable land and fresh water for their production. ${ }^{9}$ Hence, increased reliance on plant and animal proteins for bioplastic production can create substantial pressure on the high protein value food supply chain in the near future. This fact is aggravated by the fact that the world population is expected to reach 9 to 10 billion by 2050, and new and safe strategies are needed to feed the burgeoning population. ${ }^{9,10}$
Single cell proteins (SCPs), which have already been safely used as feed/food, can be viewed as potential next-generation bioplastic materials. The SCP is an innovative and alternative proteinaceous source that is extracted from dead and dry unicellular microbial biomass such as bacteria, fungi, and algae, which are cultured on agricultural wastes and industrial byproducts. ${ }^{11-13}$ Among the various species, bacterial SCP is found to be of high protein content and contains the essential amino acids. ${ }^{14,15}$ The protein content ranges from $60-80 \%$ of the total dry weight while carbohydrates, fats, vitamins, and minerals constitute the remaining cell dry weight. The advantages or benefits of the SCP over plant/animal proteins are listed as follows: (1) microbes grow at a faster rate than plants and animals and hence can outgrow the protein production by the latter species, thus resulting in a surplus protein supply, which can be utilized for non-food applications such as production of safe bioplastics. For instance, using solar energy (average solar radiance of $1800 \mathrm{~kW} \mathrm{~h} \mathrm{~m}^{-2}$ year $^{-1}$ would deliver an equivalent of $5.6 \mathrm{~kg} \mathrm{H}_{2} \mathrm{~m}^{-2}$ year $^{-1}$ via photovoltaic conversion $)$ and wind energy $\left(2 \mathrm{~W} \mathrm{~m}^{-2}\right.$ would deliver about

Received: January 17, 2021

Revised: March 26, 2021

Published: April 27, 2021 
$1300 \mathrm{~kg} \mathrm{H}_{2} \mathrm{~m}^{-2}$ year $^{-1}$ ) to support the SCP production would yield up to 67 and 3120 tons hectare year $^{-1}$ of microbial biomass, respectively, in comparison to soy production of just 3 tons hectare ${ }^{-1}$ year $^{-1}$ using renewable hydrogen, ${ }^{16,17}$ (2) because the production occurs by external cultivation of microbes on the waste products of plants and animals, the technique does not depend on high land- or water-usage and hence does not inherit the ecological and water footprint of the conventional agriculture, $^{18}$ (3) SCP production does not contribute to the carbon footprint, as in the case of conventional agriculture which utilizes industrially produced nitrogen-based fertilizers (the Haber-Bosch process results in 4-8 tons of $\mathrm{CO}_{2}$ equivalent per ton of $\mathrm{N}$ fertilizer produced). ${ }^{9}$ Additionally, the nitrate losses from agricultural land result in eutrophication and emissions of $\mathrm{N}_{2} \mathrm{O}$ greenhouse gas, thus creating high environmental havoc, whereas the used reactive nitrogen from plant and animal wastes and the released $\mathrm{CO}_{2}$ can themselves be used as $\mathrm{N}$ and $\mathrm{C}$ sources to be converted into proteins in the SCPs, ${ }^{19}$ (4) microbial growth is independent of climatic conditions and can be grown throughout the year in desired quantities, ${ }^{20}$ and (5) ease and flexibility of production, that is, SCPs can be grown in fermenters or bioreactors in aerobic or anaerobic conditions (e.g., spirulina grown on potato wastes)..$^{21,22}$ Overall, the costs of SCP produced from secondary resources, for instance, the process waters from the production of potato chips and fries, are of the order of 1-2 Euro per kg dry end product. This compares well with the price of conventional plastics and is below the price of several engineering and barrier plastics. ${ }^{23}$ It is also similar to whey powder (not pure protein, 0.5-1 Euro per $\mathrm{kg}){ }^{24}$ Hence, the technology of value-added SCP production merges well with the circular bio-economy concept toward the development of ecofriendly and sustainable bioplastics. $^{25,26}$

In this article, the development of SCP-based plastic films, for example, packaging applications and also other plastic products, is reported with an objective to develop not only an ecofriendly substitute of petroleum-based plastics but also a material that does not have to compete with food production. A series of SCP-based films were produced using the compression molding technique at three different temperatures and durations of compression with glycerol as the plasticizer. Compression molding is a useful technique because it is simple to use and the films can be produced on a large scale without the use of organic solvents for polymer solubilization. ${ }^{27-31}$ Glycerol is a large byproduct from biodiesel production, and using it here is in line with sustainable use of resources. A systematic comparative study of the films' thermal, mechanical, water vapor, and oxygen transmission properties was carried out to comprehend the behavior of the protein films at different processing conditions.

\section{EXPERIMENTAL SECTION}

2.1. Materials and Methods. The SCP was produced using the potato starch present in cutting waters, which otherwise goes to the water treatment plant (Figure S1, Supporting Information). The upgrading technology is a patented aerobic fermentation process using a mixed microbiome. ${ }^{32}$ The main components of the SCP were 66 wt \% protein (Nx6.25, Kjeldahl method-derived from EG 22/7/ 1993; nr. L179/8/10), 6.3 wt \% total fat (gravimetric method, ISO $1443), 12.5 \mathrm{wt} \%$ carbohydrates [estimated by the following formula: carbohydrates $=100 \%-(\%$ ash $)-(\%$ total fat $)-(\%$ moisture $)-$ (\% Protein)], 9.5 wt \% ash (ISO 946), and 5.7 wt \% moisture (EG
20/12/1971 L279/8/11). Glycerol (99\%) was obtained from Vinshoppen.se, Sweden. The materials were used as received.

2.2. Preparation of SCP/Glycerol Bioplastic Films. Protein films were fabricated using the compression molding technique. The flaky protein sample (Figure S1) was first ground to make a powder using a mortar and pestle. $30 \mathrm{wt} \%$ glycerol was added $(30 / 70 \mathrm{w} / \mathrm{w}$ glycerol/SCP) to the powder, which was subsequently ground thoroughly for $10 \mathrm{~min}$ using the mortar and pestle to ensure uniform mixing of the two components (Figure S1). The choice of $30 \mathrm{wt} \%$ glycerol was based on the fact that it is on a level that ensures efficient plasticization. ${ }^{33}$ The mixture was then allowed to dry at room temperature $\left(20{ }^{\circ} \mathrm{C}\right)$ for $4-5 \mathrm{~h}$. After that, the material was again ground with the mortar and pestle to obtain a fine powder of the final protein/glycerol mixture. The particle size was $302 \pm 241 \mu \mathrm{m}$, as obtained from scanning electron microscopy images. The powder was then subjected to compression molding in a Fontijne Press TP 400 (Delft, Netherlands) instrument at three different temperatures (110, 120 , and $\left.130^{\circ} \mathrm{C}\right)$ and pressing times $(5,10$, and $15 \mathrm{~min})$ with a force of $250 \mathrm{kN}$. The choice of these conditions was based on a previous work on protein materials. ${ }^{34}$ Samples are named according to the pressing conditions, that is, SCP/Gly-X-Y, for example, SCP/Gly-11010. The sample composition and pressing conditions are also summarized in Table S1. Circular molds of $10 \mathrm{~cm}$ diameter and $200 \mu \mathrm{m}$ thickness were used for making the films.

2.3. Fourier-Transform Infrared Spectroscopy. Fourier-transform infrared spectroscopy (FTIR) of the films was performed in attenuated total reflection (ATR) mode on a PerkinElmer Spectrum 400 instrument equipped with a single-reflection ATR accessory Golden Gate crystal. Before the measurement, the films were thoroughly dried in a desiccator with silica gel for 7 days. The films were then mounted on to the crystal, and the spectra were recorded from 500 to $4000 \mathrm{~cm}^{-1}$ with 16 scans at resolution of $4 \mathrm{~cm}^{-1}$. The obtained spectra were then modified in Spectrum 10.5.1 software to perform a baseline correction and deconvolution of the FTIR peaks with an enhancement factor $(\gamma)$ of 2 and smoothing filter of $70 \%$. These parameters have been used successfully in previous works. ${ }^{35}$ Then, the amide I spectral range of 1700 to $1586 \mathrm{~cm}^{-1}$ of the abovementioned baseline corrected spectra was loaded into Origin 9.1 software and the deconvoluted spectra were fitted with 10 Gaussian peaks with fixed wavelengths until the fits reached a stable minimum with an $R^{2}>0.9992 . .^{35,36}$

2.4. Tensile Testing. The tensile properties were determined using an Instron 5944 single column Universal Tensile Testing machine (MA, USA). Prior to the tests, the film samples were stored in a climate conditioning room at $23 \pm 1{ }^{\circ} \mathrm{C}$ and $50 \pm 2 \% \mathrm{RH}$ for 2 days and the tests were carried out at the same temperature and humidity conditions. Rectangular specimens of $70 \mathrm{~mm}$ length and 5 $\mathrm{mm}$ width were cut out from the films, their thickness was measured at six different points using a digital micrometer (Mitutoyo $\mathrm{AB}$, Sweden), and the mean values were taken for the tensile property calculations. The tensile test was performed with a cross-head speed of $20 \mathrm{~mm} / \mathrm{min}$ using a clamp-to-clamp distance of $20 \mathrm{~mm}$. For each sample, measurements were performed in five replicates.

2.5. Thermal Analysis. The thermal stability of the protein films was determined using thermogravimetric analysis (TGA) in a Mettler Toledo thermobalance (TGA/SDTA $851^{\mathrm{e}}$, Switzerland) at a scanning rate of $10{ }^{\circ} \mathrm{C} / \mathrm{min}$ in a nitrogen atmosphere $\left(50 \mathrm{~mL} \mathrm{~min}{ }^{-1}\right)$. The samples of $\sim 5 \mathrm{mg}$ in weight were placed in aluminum oxide crucibles and heated from 30 to $600{ }^{\circ} \mathrm{C}$.

2.6. Field Emission Scanning Electron Microscopy. The surface and the cross-sectional morphology of the films was investigated using a Hitachi S-4800 field emission scanning electron microscope. The film samples were fixed onto a field emission scanning electron microscope sample holder using a conductive carbon tape. The samples were coated with palladium/platinum in an agar high-resolution sputter coater (model $208 \mathrm{H}$ ) for $30 \mathrm{~s}$ prior to scanning.

2.7. Water Vapor Transmission Analysis. The water vapor transmission rate (WVTR) of the films was measured using the standard cup method specified in ASTM E95 (TQC Sheen 
permeability cups, surface area: $10 \mathrm{~cm}^{2}$, Article no. VF2200, Netherlands). The WVTR was measured using the desiccant method (50-0\% RH gradient over the film), where the exposed area of the films was reduced with aluminum masks (hole area: $10 \mathrm{~cm}^{2}$, MOCON Inc., USA) and sealed at the open mouth of the test cups containing anhydrous silica gel as the desiccant. The films were conditioned at 23 $\pm 1{ }^{\circ} \mathrm{C}$ and $50 \pm 2 \% \mathrm{RH}$ for $24 \mathrm{~h}$ prior to the tests. The cups were placed in a controlled humidity room $\left(23 \pm 1{ }^{\circ} \mathrm{C}\right.$ and $\left.50 \pm 2 \% \mathrm{RH}\right)$ throughout the measurements. The cups were weighed at $30 \mathrm{~min}$ intervals. The mass increase of the cups, due to moisture absorption by the desiccant from the atmosphere, was recorded to generate a plot of weight change versus time and a slope ' $n$ '. The WVTR was calculated from the slope, sample thickness $(l)$, and surface area $(A)$ as $\mathrm{WVTR}=(n \cdot l) / A$. The water vapor permeability $(\mathrm{WVP})$ was calculated by dividing the WVTR by the pressure difference over the film. The measurements were performed in triplicates.

2.8. Oxygen Transmission Rate. The oxygen permeability (OP) was determined using a Mocon Ox-Tran Twin instrument according to ASTM D 3985-95. The films were tightly sandwiched between two aluminum foils with an exposed film area of $5 \mathrm{~cm}^{2}$ and then were loaded in a diffusion cell and subsequently purged with nitrogen gas so as to measure any oxygen leakage from the instrument. After the background measurements, the samples were exposed to oxygen (99.95\%) at $23{ }^{\circ} \mathrm{C}$ and $50 \% \mathrm{RH}$ on one side and the oxygen transmission rate was normalized with respect to film thickness and oxygen pressure to obtain the OP. Two replicate measurements were performed for most samples.

2.9. Biodegradation (Soil Respiration) Tests. The biodegradability in soil was tested in a laboratory-scale trial using the ASTM D5988 standard with some modifications. The biodegradability was monitored up to 8.2 months. The soil respiration trial was set up in flasks of $1 \mathrm{~L}$ (hermetically sealed), containing $100 \mathrm{~g}$ of soil $(1 / 3$ agricultural field, $1 / 3$ meadow, and $1 / 3$ forest). The degradation of the polymers was monitored by measuring the $\mathrm{CO}_{2}$ release in the flasks, after correcting for the $\mathrm{CO}_{2}$ release in the baseline test (soil as such). Degradation of polymers is usually expressed as $\% \mathrm{CO}_{2}-\mathrm{C} /$ polymer-TOC, but as the total organic content (TOC) of the SCP materials and the home compostable bag were not known, the results in the test were expressed based on VS content [VS = organic matter [volatile solid (VS))]. Biodegradability was estimated, assuming a TOC of $45 \%$ (which is the TOC of the starch used). Duplicates of the four samples were used (incubated at $33{ }^{\circ} \mathrm{C}$ ). Sample 1 consisted of $4.5 \mathrm{~g}$ starch $/ \mathrm{kg}$ soil $(2 \mathrm{~g}$ carbon $/ \mathrm{kg}$ soil). Sample 2 consisted of $3.1 \mathrm{~g}$ SCP/Gly-110-10, which corresponded to $2.2 \mathrm{~g}$ VS per kg soil. Sample 3 consisted of $3.1 \mathrm{~g}$ of SCP/Gly-130-10, corresponding to $2.2 \mathrm{~g} \mathrm{VS} / \mathrm{kg}$ soil. Sample 4 consisted of $3.0 \mathrm{~g}$ of a home compostable bag (supermarket Lidl, $40 \%$ biobased content, conforming to the norm NFT 51-100 and HOME OK compost label) with about $3.0 \mathrm{~g} \mathrm{VS} / \mathrm{kg}$ soil. The starch was in the form of a fine powder, whereas the other samples consisted of cut films.

\section{RESULTS AND DISCUSSION}

3.1. General Film Appearance. The films were brownish, translucent, and flexible (Figure 1). Only a few single cells with intact cell walls could be observed with field emission scanning electron microscopy (Figure 2A), which then showed that the majority of the cells were disintegrated into a continuous medium/matrix, similar to the case of disintegrated cellulose pulp fibers in a grease-proof paper. ${ }^{37}$ The cross-section images (Figure 2B) also show some intact cells. However, there is no special development in features with different processing temperatures.

3.2. Mechanical Properties. The films appeared mechanically flexible, resembling a polyethylene packaging film (Figure 1). The choice of pressing conditions did not yield a noticeable difference in the general appearance of the films. The mechanical properties of packaging films are important, as they reflect the durability of the films during packing, handling,

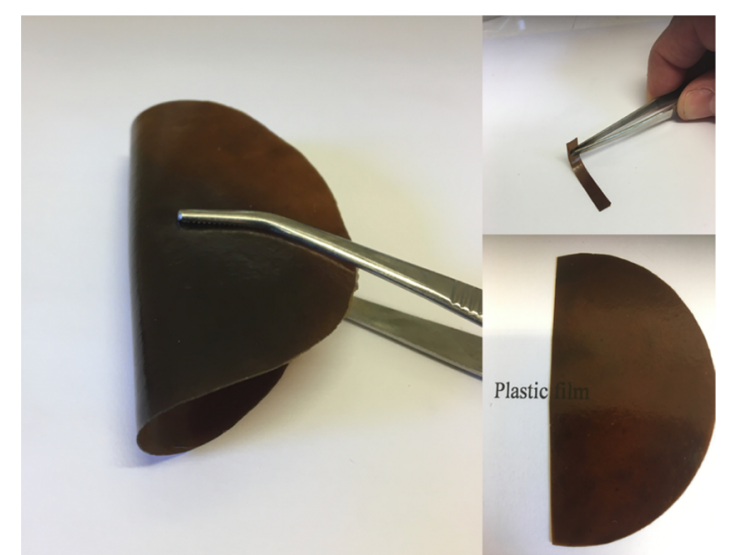

Figure 1. Flexibility and the color/translucency of the films (left: SCP/Gly-130-5, right two images: SCP/Gly-130-15).

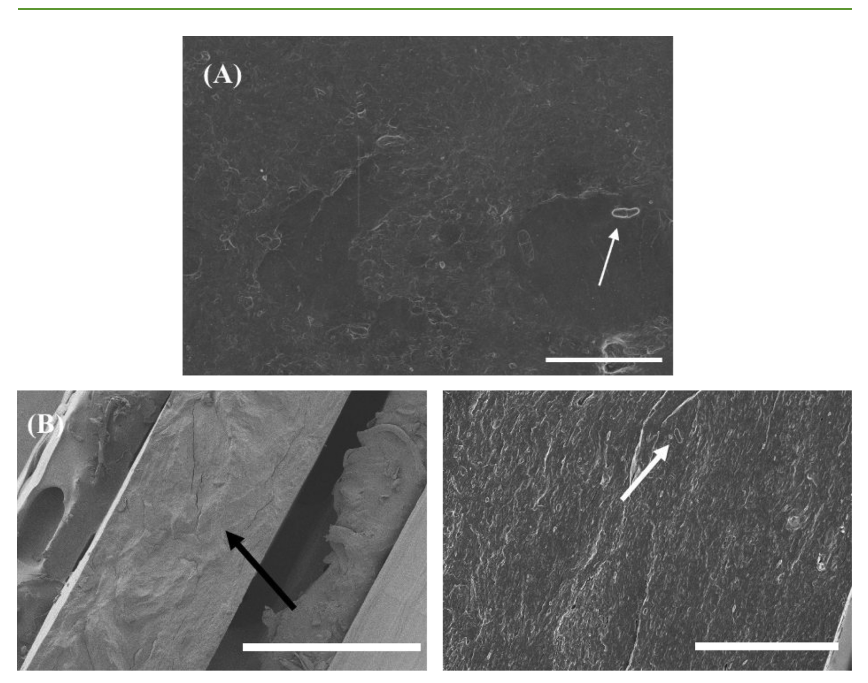

Figure 2. SEM images of (A) surface of the SCP/Gly-110-15 film (scale bar is $10 \mu \mathrm{m}$ ), and (B) cryofracture cross-section of SCP/Gly130-5 film (scale bars are 300 and $20 \mu \mathrm{m}$ for the left- and right-hand side images, respectively). White arrows point at single cells, and black arrow points at the cross section of the sample.

and storage. The tensile properties, in terms of Young's modulus, tensile strength, extensibility, and toughness, of the present protein films are included in Figure 3.

All the films had the same protein/glycerol composition, and so the changes observed in the films' properties are governed solely by the processing conditions, that is, pressing time and temperature. The stiffness (Young's modulus) and strength (maximum stress) of all films (independent of pressing time) increased overall with the increasing pressing temperature (Figure 3). The extensibility (\% elongation at break) and toughness (energy at break) showed a less distinct trend, considering all the pressing times. With exception of the strength, extensibility, and toughness at $110{ }^{\circ} \mathrm{C}$, the mechanical properties became poorer with the increasing pressing time. The changes with increasing temperature were due to heat-induced aggregation, which is often observed for proteins. On the other hand, the decreasing trend of the values with time was probably due to some degradation. It is challenging to perceive the processes (heat-induced aggregation or thermal degradation/oxidation) that will dominate the properties at a given pressing condition. The size of the 

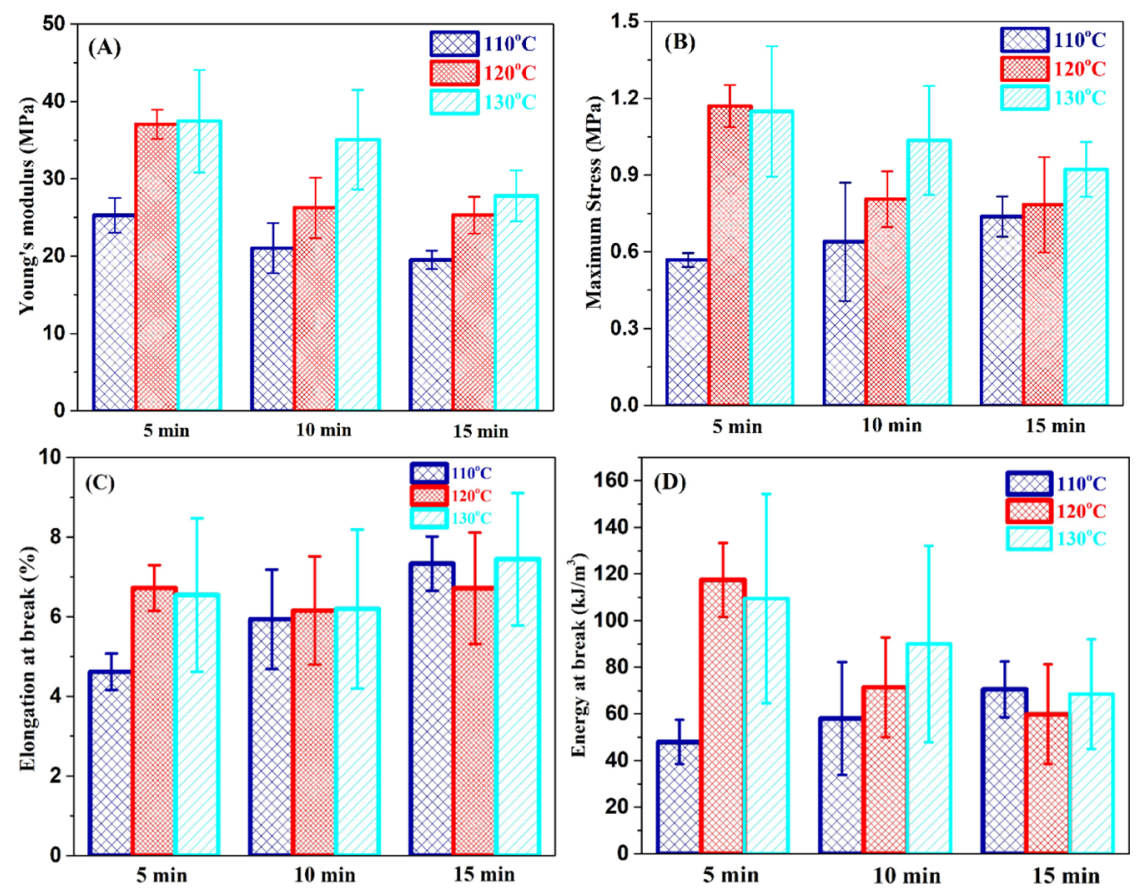

Figure 3. Tensile properties of all films at different pressing temperatures and times (A: stiffness, B: Maximum Stress, C: Extensibility and D: Energy at break).

strength and stiffness were similar to other glycerol-plasticized protein materials, whereas the ductility was on the low side. ${ }^{38}$

3.3. Thermal Properties. TGA was performed in order to determine the effect of pressing time and temperature on the thermal properties of the films. The TGA and first-derivative curves are shown in Figures S2 and 4, respectively. All the films exhibited a three-step weight loss profile similar to other proteins. ${ }^{39,40}$ The initial weight loss from 30 to about $150{ }^{\circ} \mathrm{C}$ was due to the evaporation of moisture. The weight loss in the second stage in the range $150-250{ }^{\circ} \mathrm{C}$ was attributed to mainly the loss of a glycerol plasticizer (the boiling point of glycerol is $\sim 290{ }^{\circ} \mathrm{C}$ ), and the third stage weight loss from 250-400 ${ }^{\circ} \mathrm{C}$ was due to the degradation of the residual material, rich in protein. ${ }^{39,40}$ There is a slightly enhanced thermal stability in the films pressed at higher temperature, and for a longer time, it is more clearly visible in the first-derivative plot (Figure 4). This appeared because the weight loss of glycerol shifted to higher temperature, suggesting the formation of intermolecular interactions between glycerol and amino acid groups at elevated temperatures and longer pressing time.

3.4. Water Vapor Permeability. The WVP is an important property of a food packaging material that determines the food quality during preservation and storage because excessive loss/gain of moisture through the packaging material can result in loss of food quality and decrease its shelflife. The WVP of protein-based films depends on several intrinsic and extrinsic properties. ${ }^{41}$ Intrinsic factors include amino acid composition (e.g., content of polar and non-polar amino acids), inhomogeneity, surface charge, $\mathrm{pH}$, molecular size, and three-dimensional shape. It should be noted, when comparing data in Table 1, that increasing the content of the plasticizer increases the permeability. The important extrinsic factors include film processing conditions, temperature, and relative humidity. A comparison of WVP of protein-based films with synthetic polymers is shown in Table 1 . In general,

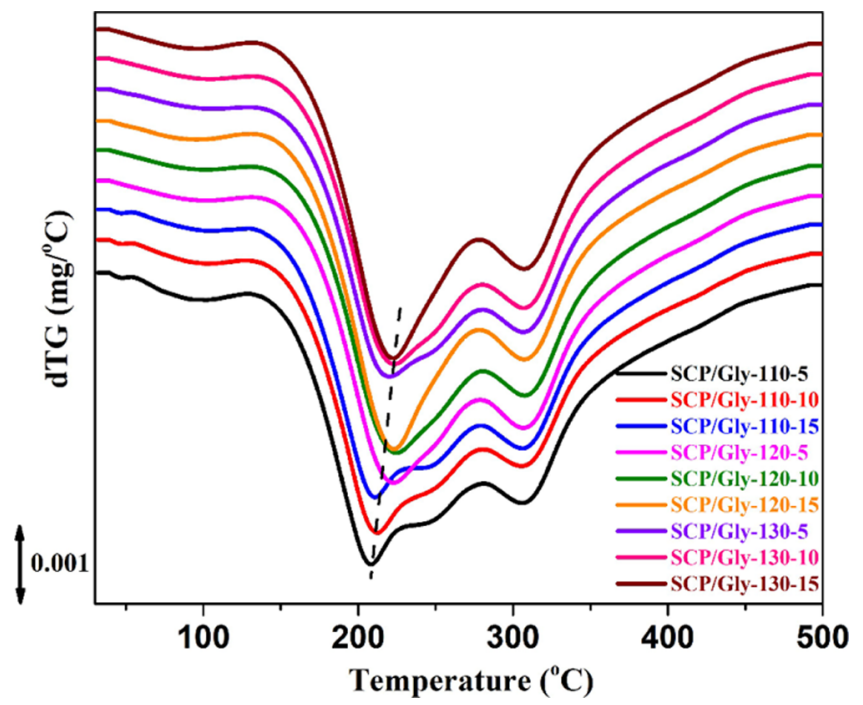

Figure 4. First derivative TGA plots of all films.

protein-based films have poor water vapor barrier properties compared to synthetic polymers such as polyethylene, poly(vinylidene chloride), and polyester. This is due to the hydrophilic functional groups of proteins, which enable greater solubility of water vapor molecules and hence a higher permeability. ${ }^{42}$ However, it is encouraging to note that the WVPs of the SCP-based films are similar or lower compared to that of other protein-based films, even considering differences in relative humidity and plasticizer content (Table 1 ). This is attributed to the high content of nonpolar amino acid moieties present in the SCP-based proteins (refer to the section on amino acid content below). Moreover, the presence of lipids (the proteins are not defatted) in the film samples contribute to the hydrophobicity in the matrix that reduces the solubility of water. It should be noted that the three protein films 
Table 1. WVP of SCP/Gly Films in Comparison to Some Well-Known Protein Films and Synthetic Polymers

\begin{tabular}{|c|c|c|c|}
\hline Sample $^{a}$ & $\begin{array}{c}\text { Temp. }\left({ }^{\circ} \mathrm{C}\right), \\
\text { RH gradient } \\
\text { (\%) }\end{array}$ & $\begin{array}{c}\text { WVP } \\
\left(\mathrm{g} \mathrm{mm} \mathrm{m}^{-2} \mathrm{~h}^{-1} \mathrm{kPa}^{-1}\right)\end{array}$ & Refs \\
\hline SCP/Gly-130-5 & $23,0 / 50$ & $0.46 \pm 0.02$ & \\
\hline SCP/Gly-130-10 & $23,0 / 50$ & $0.47 \pm 0.05$ & \\
\hline SCP/Gly-130-15 & $23,0 / 50$ & $0.48 \pm 0.01$ & \\
\hline WPI/glycerol $(70 / 30)^{*}$ & $25,0 / 100$ & 15.8 & 27 \\
\hline $\begin{array}{l}\text { wheat gluten/glycerol } \\
(67.5 / 32.5)^{*}\end{array}$ & $37.8,0 / 49$ & 1.27 & 43 \\
\hline gelatin/glycerol $(80 / 20) *$ & $25,50 / 100$ & 3.70 & 44 \\
\hline native WPI/Gly (70/30) & $25,0 / 71$ & 5.06 & 45 \\
\hline $\begin{array}{l}\text { heat denatured WPI/Gly } \\
(70 / 30)\end{array}$ & $25,0 / 71$ & 4.96 & 45 \\
\hline $\begin{array}{l}\beta \text {-lactoglobulin/Gly } \\
(70 / 30)\end{array}$ & $25,0 / 70$ & $3.90 \pm 0.29$ & 46 \\
\hline corn zein/Gly (65/35) & $0 / 97^{b}$ & 2.70 & 47 \\
\hline wheat gluten/Gly $(75 / 25)$ & $25,0 / 75$ & 0.64 & 48 \\
\hline $\begin{array}{l}\text { sodium caseinate/Gly } \\
(47 / 53)\end{array}$ & $20,0 / 45$ & 0.47 & 49 \\
\hline poly(vinylidene chloride) & $25,0 / 100$ & 0.0008 & 50 \\
\hline LDPE & $28,0 / 100$ & 0.0013 & 50 \\
\hline polyester & $25,0 / 100$ & 0.0070 & 50 \\
\hline
\end{tabular}

${ }^{a}$ All protein films were cast except those with a $*$, which were compression molded. WPI: whey protein isolate, LDPE: low-density polyethylene. ${ }^{b}$ Temperature not disclosed.

measured here had similar WVP values (within the standard deviation). The SCP-based films can, therefore, be considered a low-cost and promising alternative to other plant/animalbased protein films, for example, edible packaging applications.

3.5. Oxygen Permeability. In general, protein-based films are good barriers to oxygen in dry conditions due to their ability to form an extensive hydrogen bond network, hindering oxygen from passing through. ${ }^{51}$ This characteristic is important when improving the shelf life of certain foods, for example, high-fat foods that are known to produce rancid off-flavors due to oxidation. Additionally, oxygen might also promote microbial growth. ${ }^{52}$ Table 2 data allow for a comparison of the OP of the SCP/Gly films in Figure 5 to some proteinbased films and synthetic polymers. It is observed from the table that there was no significant difference in OP of the SCPbased films with different processing conditions, and the values were in the range of $175-205 \mathrm{~cm}^{3} \mu \mathrm{m} \mathrm{m}^{-2} \mathrm{day}^{-1} \mathrm{kPa}^{-1}$

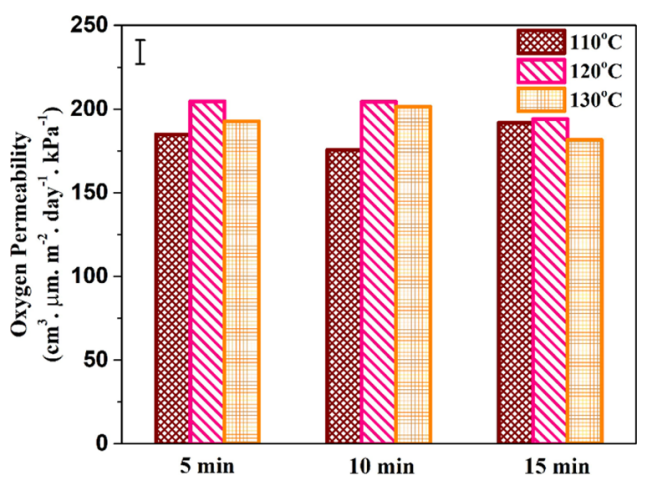

Figure 5. Oxygen permeability of all films.

(Figure 5). The changes in the molecular structure (such as aggregation) with pressing times and temperatures appear to have no significant effect on the oxygen permeation through these films. The OP values are somewhat higher than those of other protein-based films, such as whey protein isolate (WPI), $\beta$-lactoglobulin, and WG at a similar glycerol content, temperature, and relative humidity. ${ }^{46,48,53}$ It must be noted that the SCP/Gly films contain less protein than the compared materials and a relatively high content of lipids. Hence, there is possibility of improving the OP further by extraction of the pure protein fraction from the single cells for commercial applications. Increasing the protein fraction gives rise to a continuous and extensive hydrogen-bonded network, which is an important reason for low OP in protein-based films. Nevertheless, similar to other protein films, the SCP-based films demonstrate much better OP barrier properties compared to synthetic polymers such as low/high density polyethylene (LDPE and HDPE). ${ }^{55}$ Because the processing conditions do not alter the OP, they can be optimized to enhance other properties (e.g., toughness) without the possibility for unintentional lowering of OP.

3.6. Protein Conformation and Amino Acid Content. The secondary structure of the neat SCP and plasticized SCP films was studied using FTIR spectroscopy. The amide I band region from ca. 1590 to $1700 \mathrm{~cm}^{-1}$ is representative of the secondary protein structure and is mainly due to the stretching carbonyl vibration in the amide group. ${ }^{56,57}$ The origin of the peaks, their positions and assignments, and relative sizes at different pressing conditions are summarized in Tables S2 and

Table 2. Oxygen Permeability Values of Some Common Protein Films and Synthetic Polymers

\begin{tabular}{|c|c|c|c|}
\hline Sample $\mathrm{e}^{a}$ & Conditions, Temp. $\left({ }^{\circ} \mathrm{C}\right), \mathrm{RH}$ gradient (\%) & OP $\left(\mathrm{cm}^{3} \mu \mathrm{m} \mathrm{m}^{-2}\right.$ day $\left.^{-1} \mathrm{kPa}^{-1}\right)$ & refs \\
\hline$\beta$-lactoglobulin/Gly (70/30) & $23,0 / 40$ & 25 & 46 \\
\hline$(60 / 40)$ & $37,0 / 40$ & $150 \pm 2$ & \\
\hline wheat gluten/Gly $(75 / 25)$ & $25,0 / 52$ & $40 \pm 1$ & 48 \\
\hline wheat gluten/glycerol $(75 / 25)^{*}$ & $23,0 / 90$ & $22-30$ & 44 \\
\hline $\mathrm{CO}_{2}$-casein/Gly $(70 / 30)$ & $23,0 / 50$ & 144 & 54 \\
\hline unhydrolyzed WPI/Gly (3/1-0.8/1) & $23,0 / 50$ & $41-333$ & 53 \\
\hline hydrolyzed WPI/Gly $(5.5 \% \mathrm{DH})^{b}(3 / 1-0.8 / 1)$ & $23,0 / 50$ & $42-112$ & 53 \\
\hline LDPE & $23,0 / 50$ & 1870 & 55 \\
\hline HDPE & $23,0 / 50$ & 427 & 55 \\
\hline polyester & $23,0 / 50$ & 15.6 & 55 \\
\hline $\mathrm{EVOH}(70 \% \mathrm{VOH})$ & $23,0 / 50$ & 0.1 & 55 \\
\hline EVOH (70\% VOH) & $23,0 / 95$ & 12 & 55 \\
\hline
\end{tabular}

${ }^{a}$ All protein films were cast except that with a $*$, which was compression molded. WPI: whey protein isolate, LDPE: low-density polyethylene, HDPE: high-density polyethylene, EVOH: Poly(ethylene-co-vinyl alcohol), VOH: vinyl alcohol. ${ }^{b} \mathrm{DH}$ represents the degree of hydrolysis. 

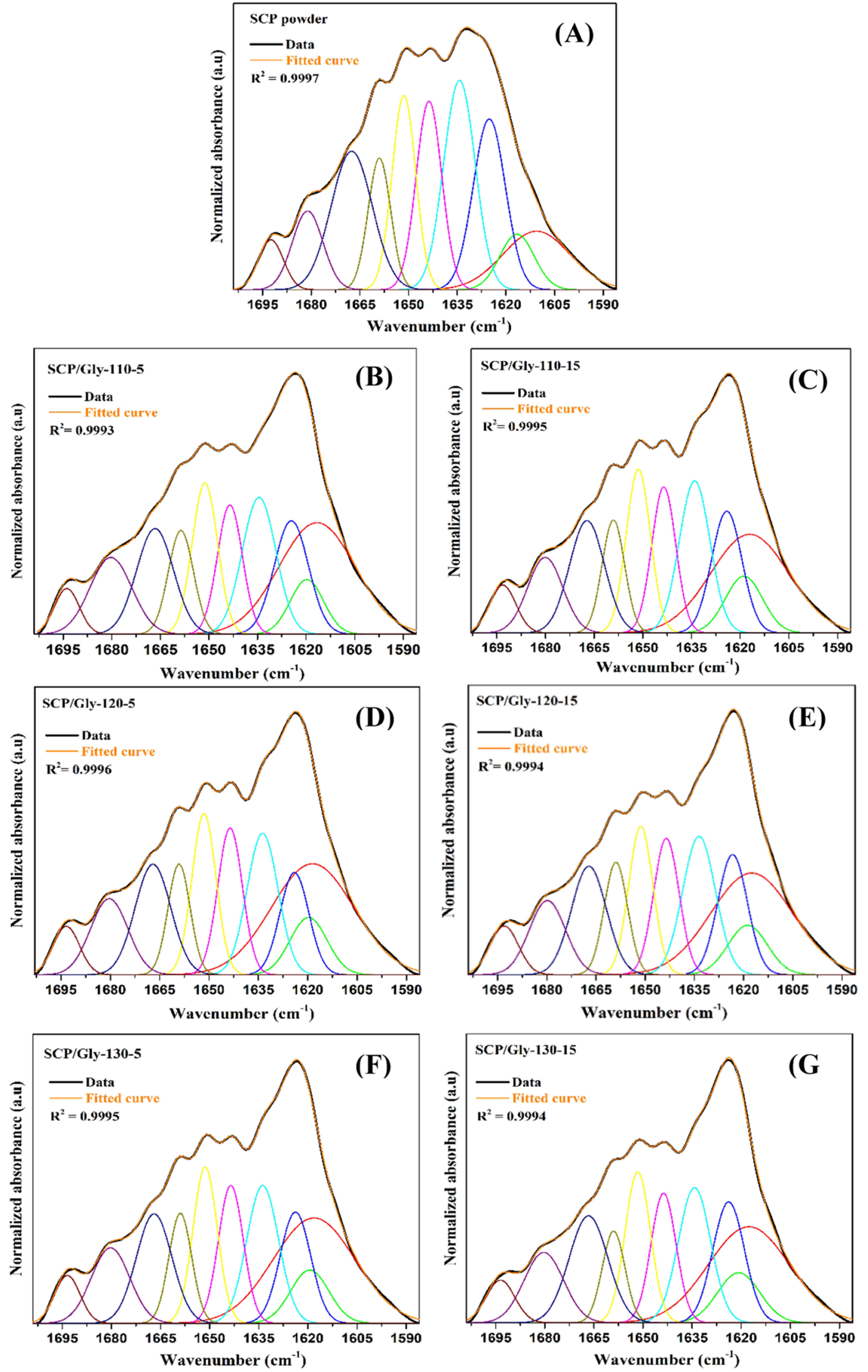

Figure 6. Fourier-deconvoluted infrared spectra (ATR) of amide I band of (A) SCP powder, and of SCP/Gly film (B) 110-5, (C) 110-15, (D) 120-5, (E) 120-15, (F) 130-5, and (G) 130-15 samples. 
S3. The deconvoluted and resolved FTIR spectra of the neat protein powder and the plasticized films are shown in Figure 6. There were no significant changes in the relative peak areas of the films prepared at different temperatures and for different periods of time. However, there was a notable difference in the relative band areas of all the films compared to the protein powder, indicating the role of thermal treatment on the secondary structure of proteins. ${ }^{58}$ The major feature is the difference in the size of the IR absorption in the low wavenumber range (peak positions between 1610 and 1625 $\mathrm{cm}^{-1}$ ), which is ascribed to the contribution from strongly hydrogen-bonded $B$-sheets. An increase in this type of $\beta$-sheets is an indication of protein aggregation, ${ }^{36}$ and consequently, the IR data showed that protein aggregation occurred during pressing. ${ }^{35}$ This can explain the overall increase in stiffness and strength at higher pressing temperatures (Figure 3). Aggregation is a process that generally increases the cohesion of a protein material. Apart from the strong hydrogen bonding, due to $\beta$-sheet formation, the reformation of disulfide crosslinks possibly also contributed to the aggregated structure, as observed in other cysteine-containing proteins such as WG and whey. ${ }^{36,58,59}$ However, the cysteine content is relatively low in the SCP protein (Table 3 ). It is also possible that isopeptide

\section{Table 3. Amino Acid Profile of the $\mathrm{SCP}^{a}$}

\begin{tabular}{lc}
\multicolumn{1}{c}{ Amino acid } & Wt \% of total protein content \\
cysteine $^{b}$ & 0.9 \\
methionine $^{b}$ & 1.9 \\
valine $^{b}$ & 7.3 \\
isoleucine $^{b}$ & 4.9 \\
leucine $^{b}$ & 8.2 \\
tyrosine $^{b}$ & 4.0 \\
phenylalanine $^{b}$ & 4.9 \\
lysine & 5.6 \\
histidine & 2.0 \\
arginine $_{\text {aspartic acid/asparagine }}$ & 6.3 \\
threonine $^{b}$ & 9.6 \\
serine $_{\text {glutamic acid/glutamine }}$ & 5.2 \\
proline $^{b}$ & 3.4 \\
glycine $^{b}$ & 12.2 \\
alanine $^{b}$ & 5.1 \\
tryptophan $^{b}$ & 7.6 \\
tron & 9.1 \\
\hline
\end{tabular}

${ }^{a}$ Determined by the Laboratorium Ecca nv, Belgium. ${ }^{b}$ Nonpolar amino acids.

bonds, which can form, for example, at high temperature, contribute to aggregation. ${ }^{60}$ These usually involve lysine, which is present at a lower content compared to whey but at a similar content as in soy protein isolates and egg white. ${ }^{61}$ It is also higher than in WG. Tyrosine can also add to aggregation by forming dityrosine cross-links. The tyrosine content is relatively high and similar to that of egg white. ${ }^{61}$ It is noteworthy that the high content of alanine and glycine with small side groups facilitates the packing of the protein chains. Additionally, it is important to note that the high content (ca. $50 \%$ ) of the amino acids that are referred to as hydrophobic ${ }^{62}$ (significantly higher than for WG and whey ${ }^{61}$ ) gives the SCP protein, among proteins, a relatively hydrophobic character. However, compared to other fully hydrophobic polymers, the protein is still hydrophilic.
3.7. Biodegradation. The soil respiration rate (baseline) was $18 \mathrm{mg} \mathrm{C}(\mathrm{kg} \mathrm{soil})^{-1} \mathrm{day}^{-1}$ in the first month of incubation, indicating that the soil used for the trials had a high microbial activity. In the second and third month of incubation, the activity was $\sim 7 \mathrm{mg} \mathrm{C}(\mathrm{kg} \mathrm{soil})^{-1} \mathrm{day}^{-1}$, and in the last 2 intervals ( 3 to 6 months and 6 to 8.4 months), the average soil respiration rate was $11-14 \mathrm{mg} \mathrm{C}(\mathrm{kg} \text { soil })^{-1}$ day $^{-1}$. A degradation of the substrates (polymers) was observed in all cases in the first 3 months. Between 3 and 6 months of incubation, the degradation of the polymers-also the starch in the positive control-essentially stopped. It was found that the $\mathrm{pH}$ in the soil at that moment (6 months incubation) was 4.85.2 in all conditions. Such a $\mathrm{pH}$ is sub-optimal, and it can explain (partly) why the polymer degradation stopped in that interval. It is commonly observed that a significant reduction in the biodegradation rate takes place as the sample surface reaches a high degree (saturation) of oxidation. According to the standard, the experiment can then be terminated. However, here, the experiment was continued. The soil $\mathrm{pH}$ was corrected in all conditions (with a phosphate buffer) after 6 months of incubation. However, although the soil was still active (11-14 $\left.\mathrm{mg} \mathrm{C}(\mathrm{kg} \mathrm{soil})^{-1} \mathrm{day}^{-1}\right)$ in the interval of 6 to 8 months, no further degradation was observed for any of the samples. Hence, most of the degradation occurred in the first 3 months, and the degradation rate "profiles" were similar for all samples. The total carbon respiration after 3 months was $660 \mathrm{mg} \mathrm{C}(\mathrm{kg}$ soil $)^{-1}$ or $15 \%$ on VS basis ( $32 \%$ of the added carbon) for the starch sample (Table 4). For the SCP/Gly-110-10 sample,

Table 4. Soil Biodegradation Data after 3 Months

\begin{tabular}{lccc}
\multicolumn{1}{c}{ Material } & $\begin{array}{c}\text { mg C } \\
(\mathrm{kg} \mathrm{soil})^{-1 a}\end{array}$ & $\begin{array}{c}\text { Degradation } \\
(\%)^{b}\end{array}$ & $\begin{array}{c}\text { Degradation } \\
(\%)^{c}\end{array}$ \\
SCP/Gly-110-10 & $206 \pm 9$ & $9.1 \pm 0.4$ & $20.3 \pm 0.9$ \\
SCP/Gly-130-10 & $214 \pm 16$ & $9.6 \pm 0.7$ & $21.2 \pm 1.6$ \\
compostable bag & $223 \pm 14$ & $7.4 \pm 0.5$ & $16.7 \pm 1.0$ \\
Starch & $660 \pm 44$ & $14.5 \pm 1.0$ & $32.3 \pm 2.1$
\end{tabular}

${ }^{a}$ Total carbon respiration. ${ }^{b}$ Total carbon respiration in \% of VS basis. ${ }^{c}$ Same as in $b$ but calculated based on a TOC of $45 \%$.

the value was $206 \mathrm{mg} \mathrm{C}(\mathrm{kg} \mathrm{soil})^{-1}$ or $9 \%$ on VS basis (assuming 45\% TOC, the degradation after 3 months of incubation was estimated to be $\sim 20 \%$ ). The values of the SCP/Gly-130-10 sample were similar to those of the SCP/Gly110-10 (Table 4). For the home compostable bag, the degradation rate was slightly lower than for the protein samples. The faster degradation of the starch was due to the larger available surface of the fine starch powder.

\section{CONCLUSIONS}

In this article, a new type of protein-based plastic has been developed that is produced from single cells cultivated from potato waste. The films were fabricated using a compression molding technique at three different pressing temperatures and times. FTIR analysis revealed protein denaturation and aggregate formation in all the thermally treated films. The pressing time and temperature affected the mechanical properties of all the films, where the tensile strength and Young's modulus increased with pressing temperatures from 110 to $130{ }^{\circ} \mathrm{C}$ due to network strengthening via aggregate formation (increases the material cohesion). However, with a longer pressing time, the strength and modulus decreased, suggesting some protein degradation. TGA revealed enhanced 
thermal stability from 200 to $250{ }^{\circ} \mathrm{C}$ for the films pressed at higher temperatures and long pressing times, revealing interactions between glycerol and amino acids at high temperatures. Whereas the WVP of the films was similar or better than other protein films, the OP values were slightly higher and could potentially be further improved by increasing the films' protein fraction (a material with high protein content will have an extensive hydrogen-bonded network, which reduces $\mathrm{O}_{2}$ permeation). However, the $\mathrm{OP}$ values were significantly better than those of the common plastic packaging materials such as LDPE and HDPE. The degradability of the SCP materials was similar to that of a household compostable bag. An advantage of the protein materials is that they do not cause problems similar to that by microplastics. They are not persistent, and they are actually a source of nutrition for plants and animals. The combined results demonstrate the potential of SCP-based bioplastic films as a sustainable alternative to environmentally demanding plant/animal-protein derived products, other biopolymeric films (polysaccharides), and synthetic polymers, for example, packaging applications. SCPs can also be contemplated to be produced from solid food wastes in the future, which is another growing research area for the development of bioplastics. ${ }^{63}$ As with other proteins, they have to be protected from high moist conditions during storage.

\section{ASSOCIATED CONTENT}

\section{(s) Supporting Information}

The Supporting Information is available free of charge at https://pubs.acs.org/doi/10.1021/acssuschemeng.1c00355.

Images of SCP flakes and powder, TG curves of all films, composition and compression molding conditions of the films, FTIR peak positions and relative sizes of the resolved peaks of the deconvoluted Amide I region bands of SCP powder and films prepared at different pressing conditions, and FTIR positions and assignments (PDF)

\section{AUTHOR INFORMATION}

\section{Corresponding Authors}

Shuvra Singha - Department of Fibre and Polymer Technology, School of Engineering Sciences in Chemistry, Biotechnology and Health, KTH Royal Institute of Technology, 10044 Stockholm, Sweden; Email: shuvras@ kth.se

Mikael S. Hedenquist - Department of Fibre and Polymer Technology, School of Engineering Sciences in Chemistry, Biotechnology and Health, KTH Royal Institute of Technology, 10044 Stockholm, Sweden; ㅈorcid.org/00000002-6071-6241; Email: mikaelhe@kth.se

\section{Authors}

Muhamed Mahmutovic - Department of Fibre and Polymer Technology, School of Engineering Sciences in Chemistry, Biotechnology and Health, KTH Royal Institute of Technology, 10044 Stockholm, Sweden

Carlos Zamalloa - Avecom NV, Wondelgem 9032, Belgium Lutgart Stragier - Avecom NV, Wondelgem 9032, Belgium Willy Verstraete - Avecom NV, Wondelgem 9032, Belgium; Center for Microbial Ecology and Technology, University of Gent, Gent 9000, Belgium
Anna J. Svagan - Department of Fibre and Polymer Technology, School of Engineering Sciences in Chemistry, Biotechnology and Health, KTH Royal Institute of Technology, 10044 Stockholm, Sweden; (1) orcid.org/00000002-4583-723X

Oisik Das - Structural and Fire Engineering Division, Department of Civil, Environmental and Natural Resources Engineering, Luleå University of Technology, Lulea 97187, Sweden

Complete contact information is available at:

https://pubs.acs.org/10.1021/acssuschemeng.1c00355

\section{Notes}

The authors declare no competing financial interest.

\section{ACKNOWLEDGMENTS}

Knut and Alice Wallenberg foundation, through the Wallenberg Wood Science Center at KTH Royal Institute of Technology, Sweden, is acknowledged for the financial support. The authors acknowledge Dr. Chandrasekar Mayandi Subramaniyam for helping with the cross-section FESEM.

\section{REFERENCES}

(1) Assad, I.; Bhat, S. U.; Gani, A.; Shah, A. Protein Based Packaging of Plant Origin: Fabrication, Properties, Recent Advances and Future Perspectives. Int. J. Biol. Macromol. 2020, 164, 707-716.

(2) Bourtoom, T. Edible Films and Coatings: Characteristics and Properties. Int. Food Res. J. 2008, 15, 237-248.

(3) Chiralt, A.; González-Martínez, C.; Vargas, M.; Atarés, L. Edible films and coatings from proteins, In Proteins in Food Processing, 2nd Ed.; Woodhead Publishing Ltd: U.K., 2018; pp 477-500.

(4) Vicente, A. A.; Cerqueira, M. A.; Hilliou, L.; Rocha, C. M. R. Protein-based resins for food packaging. Multifunctional and Nanoreinforced Polymers for Food Packaging; Woodhead Publishing Ltd: U.K., 2011, pp 610-648.

(5) Krochta, J. M. Proteins as Raw Materials for Films and Coatings: Definitions, Current Status, and Opportunities. Protein Based Films and Coatings; CRC Press: Boca Raton, FL, 2002; pp 1-42. 9781587161070 .

(6) Dubey, N. K.; Dubey, R. Edible films and coatings: An update on recent advances. Biopolymer-Based Formulations; Elsevier: Netherlands, 2020, pp 675-695. DOI: 10.1016/B978-0-12-816897-4.000278.

(7) Mohamed, S. A. A.; El-Sakhawy, M.; El-Sakhawy, M. A.-M. Polysaccharides, Protein and Lipid Based Natural Edible Films in Food Packaging: A Review. Carbohydr. Polym. 2020, 238, 116178.

(8) Kouhi, M.; Prabhakaran, M. P.; Ramakrishna, S. Edible Polymers: An Insight into Its Application in Food, Biomedicine and Cosmetics. Trends Food Sci. Technol. 2020, 103, 248-263.

(9) Matassa, S.; Batstone, D. J.; Hülsen, T.; Schnoor, J.; Verstraete, W. Can Direct Conversion of Used Nitrogen to New Feed and Protein Help Feed the World ? Environ. Sci. Technol. 2015, 49, 52475254.

(10) Ezeh, A. C.; Bongaarts, J.; Mberu, B. Global Population Trends and Policy Options. Lancet 2012, 380, 142-148.

(11) Anupama; Ravindra, P. Value-Added Food: Single Cell Protein. Biotechnol. Adv. 2000, 18, 459-479.

(12) Sharif, M.; Zafar, M. H.; Aqib, A. I.; Saeed, M.; Farag, M. R.; Alagawany, M. Single Cell Protein: Sources, Mechanism of Production, Nutritional Value and Its Uses in Aquaculture Nutrition. Aquaculture 2021, 531, 735885.

(13) Matassa, S.; Papirio, S.; Pikaar, I.; Hülsen, T.; Leijenhorst, E.; Esposito, G.; Pirozzi, F.; Verstraete, W. Upcycling of Biowaste Carbon and Nutrients in Line with Consumer Confidence: The 'Full-Gas' Route to Single Cell Protein. Green Chem. 2020, 22, 4912-4929. 
(14) García-Garibay, M.; Gómez-Ruiz, L.; Cruz-Guerrero, A. E.; Bárzana, E. Single Cell Protein, Yeasts and Bacteria. In Encyclopedia of Food Microbiology, 2nd Ed.; Elsevier: Netherlands, 2014; pp 431-438.

(15) Hülsen, T.; Hsieh, K.; Lu, Y.; Tait, S.; Batstone, D. J. Simultaneous Treatment and Single Cell Protein Production from Agri-Industrial Wastewaters Using Purple Phototrophic Bacteria or Microalgae - A Comparison. Bioresour. Technol. 2018, 254, 214-223.

(16) Matassa, S.; Boon, N.; Verstraete, W. Resource Recovery from Used Water: The Manufacturing Abilities of Hydrogen-Oxidizing Bacteria. Water Res. 2015, 68, 467-478.

(17) Ulber, R.; Sell, D.; Hirth, T. Renewable Raw Materials: New Feedstocks for the Chemical Industry; Wiley-VCH Verlag GmbH \& Co. KGaA: Wienheim, Germany, 2011. ISBN: 978-3-527-63420-0

(18) Pikaar, I.; Matassa, S.; Rabaey, K.; Bodirsky, B. L.; Popp, A.; Herrero, M.; Verstraete, W. Microbes and the Next Nitrogen Revolution. Environ. Sci. Technol. 2017, 51, 7297-7303.

(19) Pikaar, I.; Matassa, S.; Bodirsky, B. L.; Weindl, I.; Humpenöder, F.; Rabaey, K.; Boon, N.; Bruschi, M.; Yuan, Z.; van Zanten, H.; Herrero, M.; Verstraete, W.; Popp, A.; Popp, A. Decoupling Livestock from Land Use through Industrial Feed Production Pathways. Environ. Sci. Technol. 2018, 52, 7351-7359.

(20) Nasseri, A. T.; Rasoul-Ami, S.; Morowvat, M. H.; Ghasemi, Y. Single Cell Protein: Production and Process. Am. J. Food Technol. 2011, 6, 103-116.

(21) Putra, M. D.; Abasaeed, A. E.; Al-Zahrani, S. M. Prospective Production of Fructose and Single Cell Protein from Date Palm Waste. Electron. J. Biotechnol. 2020, 48, 46-52.

(22) Paraskevopoulou, A.; Athanasiadis, I.; Kanellaki, M.; Bekatorou, A.; Blekas, G.; Kiosseoglou, V. Functional Properties of Single Cell Protein Produced by Kefir Microflora. Food Res. Int. 2003, 36, 431438.

(23) www.plasticsinsight.com (date of access Jan 10, 2021).

(24) www.clal.it (date of access Jan 15, 2021).

(25) Karan, H.; Funk, C.; Grabert, M.; Oey, M.; Hankamer, B. Green Bioplastics as Part of a Circular Bioeconomy. Trends Plant Sci. 2019, 24, 237-249.

(26) Kaur, G.; Uisan, K.; Ong, K. L.; Ki Lin, C. S. Recent Trends in Green and Sustainable Chemistry \& Waste Valorisation: Rethinking Plastics in a circular economy. Curr. Opin. Green Sustain. Chem. 2018, 9, 30-39.

(27) Sothornvit, R.; Olsen, C. W.; McHugh, T. H.; Krochta, J. M. Formation Conditions, Water-vapor Permeability, and Solubility of Compression-molded Whey Protein Films. J. Food Sci. 2003, 68, 1985-1999.

(28) Sothornvit, R.; Olsen, C. W.; McHugh, T. H.; Krochta, J. M. Tensile properties of compression-molded whey protein sheets: Determination of molding condition and glycerol-content effects and comparison with solution-cast films. J. Food Eng. 2007, 78, 855-860.

(29) Sothornvit, R.; Songtip, S. Effect of Banana Flour Composition and Glycerol Content on Properties of Compression-Molded Banana Sheet. Acta Hortic. 2010, 877, 1295-1301.

(30) Sothornvit, R.; Songtip, S. Properties of compression-molded banana-based sheets compared with banana flour. Acta Hortic. 2012, 928, 243-250.

(31) Lopez, O.; Garcia, M. A.; Villar, M. A.; Gentili, A.; Rodriguez, M. S.; Albertengo, L. Thermo-compression of biodegradable thermoplastic corn starch films containing chitin and chitosan. LWT - Food Sci. Technol. 2014, 57, 106-115.

(32) Verstraete, W.; Kregersman, B.; Vervaet, S. Improved Method for Extracting Proteins from Process Water; Patent (Dutch) BE 1021400 B1, 2015.

(33) (a) Özeren, H. D.; Guivier, M.; Olsson, R. T.; Nilsson, F.; Hedenqvist, M. S. Ranking Plasticizers for Polymers with Atomistic Simulations: PVT, Mechanical Properties, and the Role of Hydrogen Bonding in Thermoplastic Starch. ACS Appl. Polym. Mater. 2020, 2, 2016-2026. (b) Rasheed, F.; Kuktaite, R.; Hedenqvist, M. S.; Gällstedt, M.; Plivelic, T. S.; Johansson, E. The use of plants as a "green factory" to produce high strength gluten-based materials. Green Chem. 2016, 18, 2782-2792. (c) Das, O.; Capezza, A. J.; Mårtensson,
J.; Dong, Y.; Neisiany, R. E.; Pelcastre, L.; Jiang, L.; Xu, Q.; Olsson, R. T.; Hedenqvist, M. S. The Effect of Carbon Black on the Properties of Plasticised Wheat Gluten Biopolymer. Molecules 2020, 25, 2279.

(34) Alipour, N.; Vinnerås, B.; Gouanvé, F.; Espuche, E.; Hedenqvist, M. S. A Protein-Based Material from a New Approach Using Whole Defatted Larvae, and Its Interaction with Moisture. Polymers 2019, 11, 287.

(35) Cho, S.-W.; Gällstedt, M.; Johansson, E.; Hedenqvist, M. S. Injection-molded Nanocomposites and Materials based on Wheat Gluten. Int. J. Biol. Macromol. 2011, 48, 146-152.

(36) Ye, X.; Junel, K.; Gällstedt, M.; Wei, X.-F.; Lendel, C.; Hedenqvist, M. S.; Hedenqvist, M. S. Protein/Protein Nanocomposite Based on Whey Protein Nanofibrils in a Whey Protein Matrix. ACS Sustainable Chem. Eng. 2018, 6, 5462-5469.

(37) Aulin, C.; Ström, G. Multilayered Alkyd Resin/Nanocellulose Coatings for Use in Renewable Packaging Solutions with a High Level of Moisture Resistance. Ind. Eng. Chem. Res. 2013, 52, 2582-2589.

(38) Gällstedt, M.; Hedenqvist, M. S.; Türe, H. Production, Chemistry and Properties of Proteins. In Films and Coatings from Renewable Resources-An Applications Perspective; Plackett, D., Ed.; Blackwell Publishing Ltd./John Wiley \& Sons Ltd.: Chichester, 2011, pp 107-132.

(39) Parveen, S.; Chaudhury, P.; Dasmahapatra, U.; Dasgupta, S. Biodegradable Protein Films from Gallic Acid and the Cataractous Eye Protein Isolate. Int. J. Biol. Macromol. 2019, 139, 12-20.

(40) Osorio-Ruiz, A.; Avena-Bustillos, R. J.; Chiou, B.-S.; RodríguezGonzález, F.; Martinez-Ayala, A.-L. Mechanical and Thermal Behavior of Canola Protein Isolate Films as Improved by Cellulose Nanocrystals. ACS Omega 2019, 4, 19172-19176.

(41) Dangaran, K.; Tomasula, P. M.; Qi, P. Structure and Function of Protein-Based Edible Films and Coatings. In Edible Films and Coatings for Food Applications; Springer Science+Business Media, LLC: New York, USA, 2009, pp 25-56.

(42) Bourtoom, T. Edible Protein Films: Properties Enhancement. Int. Food Res. J. 2009, 16, 1-9.

(43) Gällstedt, M.; Mattozzi, A.; Johansson, E.; Hedenqvist, M. S. Transport and Tensile Properties of Compression-Molded Wheat Gluten Films. Biomacromolecules 2004, 5, 2020-2028.

(44) Ciannamea, E. M.; Stefani, P. M.; Ruseckaite, R. A. Physical and mechanical properties of compression molded and solution casting soybean protein concentrate based films. Food Hydrocolloids 2014, 38, 193-204.

(45) Perez-Gago, M. B.; Nadaud, P.; Krochta, J. M. Water Vapor Permeability, Solubility, and Tensile Properties of Heat-denatured versus Native Whey Protein Films. J. Food Sci. 1999, 64, 1034-1037.

(46) Maté, J. I.; Krochta, J. M. Comparison of Oxygen and Water Vapor Permeabilities of Whey Protein Isolate and $\beta$-Lactoglobulin Edible Films. J. Agric. Food Chem. 1996, 44, 3001-3004.

(47) Huo, W.; Wei, D.; Zhu, W.; Li, Z.; Jiang, Y. High-elongation zein films for flexible packaging by synergistic plasticization: Preparation, structure and properties. J. Cereal Sci. 2018, 79, 354361.

(48) Tanada-Palmu, P. S.; Grosso, C. R. F. Development and characterization of edible films based on gluten from semi-hard and soft Brazilian wheat flours (development of films based on gluten from wheat flours). Cienc. Tecnol. Aliment. 2003, 23, 264-269.

(49) Khwaldia, K.; Banon, S.; Desobry, S.; Hardy, J. Mechanical and Barrier Properties of Sodium Caseinate-Anhydrous Milk Fat Edible Films. Int. J. Food Sci. Technol. 2004, 39, 403-411.

(50) Shellhammer, T. H.; Krochta, J. M. Water Vapor Barrier and Rheological Properties of Simulated and Industrial Milk Fat Fractions. Trans. ASAE 1997, 40, 1119-1127.

(51) Perez-Gago, M. B.; Krochta, J. M. Drying Temperature Effect on Water Vapor Permeability and Mechanical Properties of Whey Protein-Lipid Emulsion Films. J. Agric. Food Chem. 2000, 48, 26872692.

(52) Cichello, S. A. Oxygen Absorbers in Food Preservation: A Review. J. Food Sci. Technol. 2015, 52, 1889-1895. 
(53) Sothronvit, R.; Krochta, J. M. Oxygen Permeability and Mechanical Properties of Films from Hydrolyzed Whey Protein. J. Agric. Food Chem. 2000, 48, 3913-3916.

(54) Tomasula, P. M.; Yee, W. C.; Parris, N. Oxygen Permeability of Films Made from CO2-Precipitated Casein and Modified Casein $\dagger$. J. Agric. Food Chem. 2003, 51, 634-639.

(55) Salame, M. Barrier Polymers, In The Wiley Encyclopedia of Packaging Technology; John Wiley \& Sons: New York, 1986; pp 4854. ISBN-13: 978-0471809401

(56) Mangavel, C.; Barbot, J.; Popineau, Y.; Guéguen, J. Evolution of Wheat Gliadins Conformation during Film Formation: A Fourier Transform Infrared Study. J. Agric. Food Chem. 2001, 49, 867-872.

(57) Roy, S.; Weller, C. L.; Gennadios, A.; Zeece, M. G.; Testin, R. F. Physical and Molecular Properties of Wheat Gluten Films Cast from Heated Film-Forming Solutions. J. Food Sci. 1999, 64, 57-60.

(58) Das, O.; Hedenqvist, M. S.; Johansson, E.; Olsson, R. T.; Loho, T. A.; Capezza, A. J.; Singh Raman, R. K.; Holder, S. An all-gluten biocomposite: Comparisons with carbon black and pine char composites. Composites, Part A 2019, 120, 42-48.

(59) Das, O.; Rasheed, F.; Kim, N. K.; Johansson, E.; Capezza, A. J.; Kalamkarov, A. L.; Hedenqvist, M. S. The Development of Fire and Microbe Resistant Sustainable Gluten Plastics. J. Cleaner Prod. 2019, $222,163-173$.

(60) Rombouts, I.; Lagrain, B.; Brunnbauer, M.; Koehler, P.; Brijs, K.; Delcour, J. A. Identification of Isopeptide Bonds in Heat-Treated Wheat Gluten Peptides. J. Agric. Food Chem. 2011, 59, 1236-1243.

(61) Norton, L. E.; Wilson, G. J.; Layman, D. K.; Moulton, C. J.; Garlick, P. J. Leucine content of dietary proteins is a determinant of postprandial skeletal muscle protein synthesis in adult rats. Nutr. Metab. 2012, 9, 67.

(62) Faltejsková, K.; Jakubec, D.; Vondrášek, J. Hydrophobic Amino Acids as Universal Elements of Protein-Induced DNA Structure Deformation. Int. J. Mol. Sci. 2020, 21, 3986.

(63) Acquavia, M. A.; Pascale, R.; Martelli, G.; Bondoni, M.; Bianco, G. Natural Polymeric Materials: A Solution to Plastic Pollution from the Agro-Food Sector. Polymers 2021, 13, 158. 